\title{
Habitat dan Distribusi Kerang Kepah (Polymesoda erosa) di Kawasan Mangrove Muara Sungai Tiram Kabupaten Padang Pariaman Sumatera Barat
}

\section{Habitat and Distribution of Kerang Kepah (Polymesoda erosa) in Tiram Mangrove Estuary District Padang Pariaman West Sumatera}

\author{
Ranti Wulandari ${ }^{1 *}$, Syafruddin Nasution ${ }^{1}$, Afrizal Tanjung ${ }^{1}$ \\ ${ }^{1}$ Jurusan Ilmu Kelautan, Fakultas Perikanan dan Kelautan, Universitas Riau \\ Kampus Bina Widya Jl. HR. Soebrantas Km 12.5, Pekanbaru, 28293 \\ email: wulandariranti669@yahoo.com
}

(Received: 01 November 2021; Accepted: 25 Februari 2022)

\begin{abstract}
ABSTRAK
Penelitian ini dilakukan pada Bulan Oktober 2019 di kawasan mangrove muara Sungai Tiram, Kabupaten Padang Pariaman, Sumatera Barat. Penelitian ini bertujuan untuk mengetahui karakteristik habitat dan distribusi kerang kepah (Polymesoda erosa) di kawasan mangrove muara Sungai Tiram. Metode yang digunakan pada penelitian ini adalah metode survei. Kawasan mangrove di lokasi penelitian dibagi menjadi 3 zona yaitu upper, middle, dan lower dengan jarak antar zona sejauh $30 \mathrm{~m}$ yang terbagi atas 5 titik sampling pada setiap zona dengan plot berukuran 1 $\mathrm{x} 1 \mathrm{~m}$ dengan jarak masing-masing titik sampling sejauh $40 \mathrm{~m}$. Hasil penelitian menunjukkan bahwa karakterisik habitat kerang kepah memiliki nilai rata-rata suhu $30^{\circ} \mathrm{C}$, salinitas $6 \mathrm{ppt}$, pH 6 , kandungan bahan organik total sedimen berkisar antara 2,48-2,98\%, dan bahan padatan tersuspensi memiliki nilai berkisar anta $10-20 \mathrm{mg} / \mathrm{L}$. Kelimpahan tergolong rendah dan tidak ada perbedaan kelimpahan antar zona pengamatan. Pola distribusi bersifat merata yang didominasi ukuran 3,52$3,91 \mathrm{~cm}$.
\end{abstract}

Kata Kunci: Habitat, Distribusi, Polymesode erosa, Mangrove

\begin{abstract}
The research was conducted in October 2019 in Tiram estuary mangrove, the District of Padang Pariaman West Sumatra. This study aims were to determine the characteristics of the habitat, abundance, size-frequency distribution, and the distribution pattern of Polymesoda erosa in Tiram estuary mangrove. The method used in this study was a survey method. Mangrove area was divided into 3 zones: the upper, middle, and lower with the distance between the zones as far as 30 $\mathrm{m}$. Each zone divided into 5 sampling points using a $1 \mathrm{x} 1 \mathrm{~m}$ plot with the distance of each sampling point about $40 \mathrm{~m}$. The results showed that the habitat characteristic of $P$. erosa has an average value of $30^{\circ} \mathrm{C}, 6 \mathrm{ppt}$ salinity, $\mathrm{pH} 6$, total organic matter content of the sediment ranged from 2,48 to $2,98 \%$, and suspended solids material values ranging $10-20 \mathrm{mg} / \mathrm{L}$. Abundance was low and there was no difference in abundance between the observation zone. The distribution pattern was uneven which was dominated sizes from 3.52 to $3.91 \mathrm{~cm}$
\end{abstract}

Keyword: Habitat, Distribution, Polymesoda erosa, Mangrove

\section{Pendahuluan}

Kerang mempunyai bentuk dan ukuran cangkang yang bervariasi. Kerang hidup pada semua tipe perairan yaitu air tawar, estuari, dan perairan laut. Kerang laut terdistribusi dari daerah intertidal, perairan laut dangkal dan ada yang mendiami perairan laut dalam. Kehidupan kerang dipengaruhi oleh substrat dasar perairannya. Kerang biasanya hidup di daerah yang memiliki substrat liat berpasir atau berlumpur yang kaya bahan organik yang akan mempengaruhi ketersediaan makanan. 
Faktor biologi yang mempengaruhi kehidupan kerang adalah fitoplankton, zooplankton, zat organik tersuspensi dan makhluk hidup di lingkungannya (Dwiono, 2003).

Kerang kepah biasanya membutuhkan habitat yang spesifik di hutan mangrove. Umumnya kerang kepah ini hidup di hutan mangrove air payau dan sungai-sungai besar, serta dapat bertahan pada kondisi $\mathrm{pH}$ yang rendah dan fluktuasi salinitas yang tinggi. Kerang kepah diminati oleh masyarakat dan mudah didapatkan di kawasan mangrove muara Sungai Tiram. Pengambilan kerang kepah oleh masyarakat di daerah muara Sungai Tiram tidak melihat ukuran kerang tersebut. Sedangkan kerang kepah di perairan tersebut sudah mulai berkurang akibat pengambilan kerang yang bersifat kontinue.

Muara Sungai Tiram yang bermuara langsung ke Pantai Tiram terletak di Kecamatan Ulakan Tapakis Kabupaten Padang Pariaman Provinsi Sumatera Barat memiliki luas pantai sekitas 10,5 hektar dengan garis pantai yang panjang. Muara Sungai Tiram memiliki mangrove jenis Rhizophora sp. Kecamatan Ulakan Tapakis dilaui oleh 2 buah muara sungai yaitu Muara Sungai Ulakan dan Muara Sungai Tapakis (muara Sungai Tiram).

Berdasarkan penelitian Kelana et al. (2015) rata-rata kelimpahan P.erosa di Ekosistem Mangrove Cagar Alam Leuweung Sancang berkisar antara $0-18 \quad \mathrm{ind} / \mathrm{m}^{2}$, kawasan mangrove Pantai Pasir Padi berkisar antara $1,75-3 \mathrm{ind} / \mathrm{m}^{2}$ (Melinda et al., 2015). Pada penelitian Hutan Mangrove Desa Sungai Bakau Kecil Kabupaten Mempawah berkisar antara 2,67-3 ind $/ \mathrm{m}^{2}$ (Marwanto et al., 2018). Tidak adanya informasi mengenai kelimpahan kerang kepah di kawasan mangrove muara Sungai Tiram sehingga peneliti tertarik untuk melakukan penelitian mengenai kerang kepah di kawasan mangrove muara Sungai Tiram.

\section{Metode Penelitian}

\subsection{Waktu dan Tempat}

Penelitian ini dilaksanakan pada Bulan Oktober 2019 di kawasan mangrove muara Sungai Tiram Kabupaten Padang Pariaman Sumatera Barat. Selanjutnya sampel kerang yang didapat dianalisis di Laboratorium Biologi Laut, sedangkan analisis bahan organik dan analisis konsentrasi bahan padatan tersuspensi dilakukan di
Laboratorium Kimia Laut Jurusan Ilmu Kelautan Fakultas Perikanan dan Kelautan Universitas Riau. (Gambar 1).

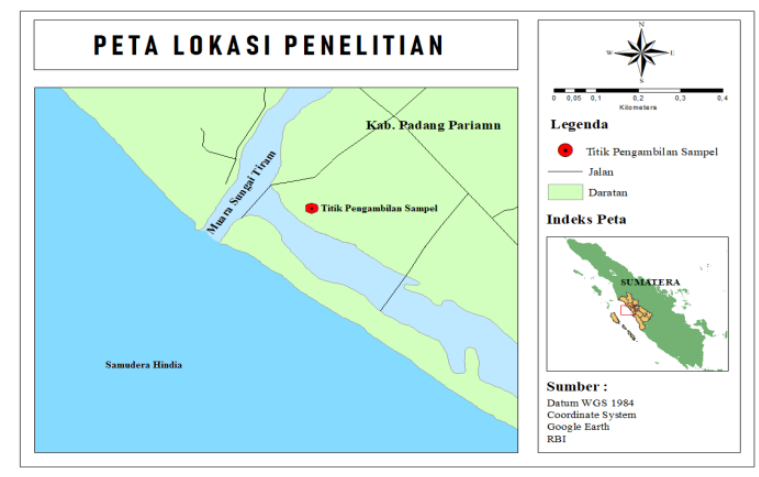

Gambar 1. Letak Muara Sungai Tiram sebagai Lokasi Pengamatan

\subsection{Metode Penelitian}

Metode yang digunakan dalam penelitian ini adalah metode survey.

\subsection{Prosedur Penelitian}

\subsubsection{Parameter Kualitas Perairan}

Parameter kualitas perairan yang diukur yaitu suhu, salinitas, dan $\mathrm{pH}$. Pengukuran dilakukan sebanyak 3 kali pengulangan. Lokasi penelitian dibagi menjadi 3 zona yaitu upper (Zona I), middle (Zona II) dan lower (Zona III) dengan jarak antar zona sejauh 30 $\mathrm{m}$ yang terbagi atas 5 titik sampling yang berukuran $1 \times 1 \mathrm{~m}$ dengan masing-masing jarak antar titik sampling $40 \mathrm{~m}$.

\subsubsection{Kandungan Bahan Organik Total Sedimen \\ Pengambilan kelimpahan kerang sangat} berkaitan dengan bahan organik karena bahan organik merupakan bahan makanan yang sangat penting untuk organisme kerang serta habitat bagi organisme. Pengambilan sampel sedimen untuk analisis bahan organik dilakukan satu kali, sebanyak 100 g pada setiap titik sampling menggunakan sekop. Untuk mengetahui kandungan zat organik total maka dilakukan perhitungan dengan rumus (Radojevic dan Bashkin, 1999) :

Zat Organik Total $=\frac{a-b}{c} \times 100 \%$ Keterangan:
$\mathrm{a}=$ berat cawan dan berat sampel sedimen sebelum pembakaran $550^{\circ} \mathrm{C}$ atau sesudah pengeringan $105^{\circ} \mathrm{C}$
$\mathrm{b}=$ berat cawan dan berat sampel sedimen sesudah pembakaran $550^{\circ} \mathrm{C}$ 
$\mathrm{c}=$ berat sampel

\subsubsection{Bahan Padatan Tersuspensi}

Pengambilan sampel bahan padatan tersuspensi dilakukan di permukaan perairan pada titik sampling yang telah ditentukan dan dilakukan saat surut menuju pasang, hal ini dikarenakan umumnya kadar padatan tersuspensi yang tinggi terjadi pada saat tersebut (Solihudin et al., 2011). Untuk menentukan bahan padatan tersuspensi maka dilakukan perhitungan dengan menggunakan rumus (SNI 06-6989-3,2004) :

$$
\operatorname{TSS}(\mathrm{mg} / \mathrm{L})=\frac{(\mathrm{A}-\mathrm{B}) \times 1000}{\mathrm{~V}}
$$

Keterangan :

$$
\begin{aligned}
& \mathrm{A}=\begin{array}{l}
\text { Berat kertas saring }+ \text { residu kering } \\
(\mathrm{mg})
\end{array} \\
& \mathrm{B}=\text { Berat kertas saring }(\mathrm{mg}) \\
& \mathrm{V}=\text { Volume contoh uji }(\mathrm{mL})
\end{aligned}
$$

\subsection{Parameter yang Diamati}

\subsubsection{Kelimpahan P.erosa}

Kelimpahan bivalva dihitung berdasarkan pendapat (Snedecor dan Cochran, 1980) dengan rumus berikut:

Keterangan :

$$
K=\frac{X i}{n i}
$$

$$
\begin{aligned}
& \left.\mathrm{K}=\text { Kelimpahan suatu jenis (ind } / \mathrm{m}^{2}\right) \\
& \mathrm{Xi}=\text { Jumlah individu (ind) } \\
& \mathrm{ni}=\text { Luas plot }\left(\mathrm{m}^{2}\right)
\end{aligned}
$$

\subsubsection{Pola Distribusi P.erosa}

Untuk melihat pola distribusi pada setiap stasiun digunakan Indeks Sebaran
Morisita (Id) yang merujuk pada Brower et al. (1990) :

Keterangan :

$$
I d=n \frac{\sum x i^{2}-N}{N(N-1)}
$$

$$
\begin{aligned}
\mathrm{Id} & =\text { Indeks Sebaran Morisita } \\
\mathrm{n} & = \\
& \text { jumlah unit pengambilan contoh } \\
\mathrm{xi} & =\text { jumlah individu jenis pada tiap plot } \\
\mathrm{N} & =\begin{array}{l}
\text { jumlah total individu jenis dari } \\
\text { semua plot }
\end{array}
\end{aligned}
$$

Hasil ini dikelompokkan menjadi 3 kriteria, yaitu:

$\mathrm{Id}<1 \quad \rightarrow$ penyebaran individu merata

$\mathrm{Id}=1 \rightarrow$ penyebaran individu acak

Id $>1 \rightarrow$ penyebaran individu mengelompok

\subsubsection{Distribusi Frekuensi Ukuran P.erosa}

Untuk mendapatkan kelas ukuran panjang P.erosa yang ditemukan, maka dibuat kelas interval menurut Nugroho et al. (2009), dengan rumus:

$$
k=1+3,322 \log n
$$

Keterangan :

$\mathrm{k}=$ banyak kelas

$\mathrm{n}=$ banyak data

\section{Hasil dan Pembahasan}

\subsection{Parameter Kualitas Perairan}

Rata-rata hasil pengukuran parameter kualitas perairan di kawasan mangrove muara Sungai Tiram dapat dilihat pada Tabel 1.

Tabel 1. Rata-rata Parameter Kualitas Perairan pada masing-masing Zona Pengamatan

\begin{tabular}{lllccc}
\hline \multirow{2}{*}{ No. } & Parameter & Satuan & \multicolumn{3}{c}{ Zona } \\
\cline { 3 - 5 } & Suhu & ${ }^{\circ} \mathrm{C}$ & 31 & II & III \\
\hline 2. & Salinitas & $\mathrm{ppt}$ & 6 & 30 & 31 \\
3. & $\mathrm{pH}$ & & 6 & 7 & 6 \\
\hline
\end{tabular}

Berdasarkan pengamatan dan pengukuran yang telah dilakukan didapatkan hasil bahwa kualitas perairan kawasan hutan mangrove muara Sungai Tiram tergolong cukup mendukung untuk pertumbuhan kerang. Hasil pengukuran suhu berkisar antara 30$31^{\circ} \mathrm{C}$. Suhu perairan terendah terdapat pada Zona II, sedangkan suhu tertinggi terdapat pada Zona I dan Zona III. Kisaran suhu di kawasan tersebut masih normal dan dapat mendukung keberadaan bivalva. Hal ini didukung oleh Suryanto dan Utojo (2002) menyatakan bahwa suhu optimum untuk mendukung kehidupan bivalva berkisar antara 28-32 ${ }^{\circ} \mathrm{C}$.

Hasil pengamatan terhadap salinitas di kawasan mangrove muara Sungai Tiram berkisar antara 6-7 ppt. Salinitas di kawasan ini memiliki kisaran nilai relatif rendah dikarenakan pada lokasi tersebut berdekatan 
dengan muara sungai. Kerang kalandue (P.erosa) di Teluk Kendari ditemukan pada kisaran salinitas 21,3-35\% (Akbar et al., 2014). Hasil pengukuran $\mathrm{pH}$ selama penelitian di kawasan mangrove muara Sungai Tiram berkisar antara 6-7. Nilai $\mathrm{pH}$ di perairan ini berada dalam kondisi normal dan tergolong cukup mendukung untuk pertumbuhan bivalva. Sebagian besar biota akuatik sensitif terhadap perubahan $\mathrm{pH}$ dan menyukai kisaran pH sekitar 7-8,5 (Effendi, 2003). Penelitian di Teluk Kendari kerang P. erosa ditemukan pada pH 6-7 (Akbar et al., 2014).

\subsection{Kandungan Bahan Organik Total Sedimen}

Ketersediaan bivalva di alam didukung oleh adanya kandungan bahan organik di suatu perairan. Berdasarkan analisa yang telah dilakukan didapatkan kandungan bahan organik di kawasan mangrove muara Sungai Tiram berkisar antara 2,48\% - 2,98\%. Bahan organik tertinggi berada pada zona I, sedangkan bahan organik terendah berada pada zona III. Hasil analisis kandungan bahan organik sedimen di kawasan ini memiliki kandungan bahan organik yang bersifat homogen dan tidak terdapat perbedaan yang signifikan antar zona.

Tingginya kandungan bahan organik disebabkan oleh vegetasi mangrove sebagai penyumbang bahan organik dari serasah pohon mangrove akan membentuk partikelpartikel organik dalam sedimen (Susanti et al., 2013). Hal ini sesuai sesuai dengan pendapat Nontji (2007) menyatakan bahwa kandungan bahan organik yang terdapat di perairan lebih kurang $90 \%$ berasal dari vegetasi mangrove. Luruhan daun mangrove yang jatuh ke perairan merupakan sumber bahan organik yang penting dalam rantai makanan. Kunci kesuburan perairan sekitar kawasan mangrove terletak pada masukan bahan organik yang berasal dari guguran daun mangrove tersebut. Bahan organik menjadi sumber makanan bagi bivalvia (Hamidah, 2000).

\subsection{Bahan Padatan Tersuspensi}

Hasil analisis kandungan zat padat tersuspensi pada kawasan mangrove muara Sungai Tiram memiliki zat padat tersuspensi yang tidak bervariasi dan tidak terdapat perbedaan yang signifikan. Kandungan zat padat tersuspensi di kawasan ini berkisar antara $10-20 \mathrm{mg} / \mathrm{L}$. Menurut hasil penelitian Jewlaika et al. (2014) dimana bila semakin keruh suatu perairan maka nilai total padatan tersuspensi semakin tinggi pula dan kecerahan suatu perairan semakin rendah. Hal tersebut juga mempengaruhi biota-biota air untuk mendapatkan intensitas cahaya matahari. Bila suatu perairan memiliki nilai kekeruhan atau total padatan tersuspensi yang tinggi maka semakin rendah nilai produktivitas suatu perairan.

Perubahan atau naik turunnya nilai bahan padatan tersuspensi tidak selalu diikuti oleh naik turunnya nilai kekeruhan secara linier, karena bahan-bahan yang menyebabkan kekeruhan perairan dapat terdiri atas berbagai bahan yang sifat dan beratnya berbeda sehingga tidak termasuk dalam bobot residu bahan padatan tersuspensi yang sebanding. Hal ini juga berhubungan dengan prinsip pengukuran yang berbeda antara kekeruhan dengan Total Suspendid Solid (Widigdo, 2000).

\subsection{Kelimpahan P.erosa}

Hasil pengukuran kelimpahan kerang kepah ( $P$. erosa) di kawasan mangrove muara Sungai Tiram diperoleh kelimpahan tertinggi ditemukan pada zona I dengan jumlah total individu sebanyak 64 individu dengan ratarata kelimpahan sebesar $12,8 \mathrm{ind} / \mathrm{m}^{2}$, sedangkan kelimpahan terendah ditemukan pada zona III dengan jumlah total individu sebanyak 50 individu dengan rata-rata kelimpahan sebesar $10 \mathrm{ind} / \mathrm{m}^{2}$. Kelimpahan antar zona tidak terlalu signifikan perbedaannya karena bahan organik dan bahan padatan tersuspensi di kawasan tersebut juga tidak memiliki perbedaan. Berdasarkan hasil dari Uji ANOVA menunjukkan kelimpahan kerang kepah memiliki nilai signifikan 0,256 $(>0,05)$ dimana tidak terdapat perbedaan kelimpahan kerang kepah antar zona pengamatan.

Secara umum meningkatnya kandungan bahan organik yang terdapat dalam sedimen pada setiap zona akan diikuti pula oleh meningkatnya kelimpahan kerang $P$. erosa. Bahan organik substrat mempengaruhi kepadatan dan kelimpahan makrozoobenthos (Habonaran et al., 2015). Jenis bivalva merupakan jenis yang banyak ditemukan pada substrat yang berlumpur (Dahuri, 2004). Tingginya kandungan bahan organik pada 
sedimen di sepanjang sungai terdapat tumbuhan mangrove yang serasah daunnya dapat meningkatkan kandungan bahan organik di substrat dasarnya. Namun pengaruh fisik juga mempengaruhi kelimpahan diantaranya pengambilan kerang yang terus-menerus oleh masyarakat juga akan mempengaruhi kerang P. erosa (Pemuji et al., 2015). Perbedaan kisaran kelimpahan dari beberapa jenis bivalvia sangat dipengaruhi oleh kondisi fisika kimia perairan, maupun tingkat eksploitasi dari bivalvia tersebut yang berbeda-beda di setiap lokasi penelitian. Kondisi fisika dan kimia perairan sangat mendukung keberadaan bivalvia (Alfiansyah, 2014).

Hasil dari perhitungan rata-rata kelimpahan kerang kepah antar zona yang ditemukan di kawasan mangrove muara Sungai Tiram dapat dilihat pada Gambar 2.

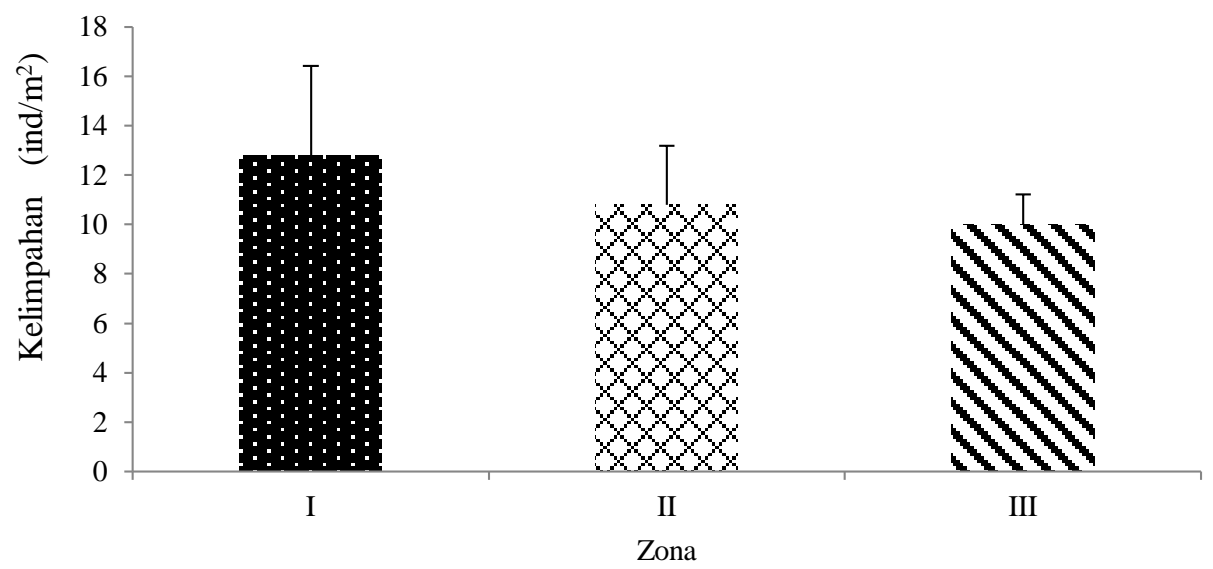

Gambar 2. Kelimpahan ( \pm Standar Deviasi) P. erosa pada Masing-masing Zona Pengamatan di Kawasan Mangrove Muara Sungai Tiram

\subsection{Pola Distribusi P.erosa}

Hasil perhitungan Indeks Sebaran Morisita kerang kepah diketahui bahwa pola distribusinya bersifat acak pada zona I dan bersifat mengelompok pada zona II dan III. Menurut Junaidi et al. (2010) pola sebaran yang seragam dikarenakan ketika pengambilan sampel kondisi perairan dalam keadaan surut, sehingga luas permukaan air lebih kecil. Adanya perubahan kondisi lingkungan baik sifat fisik dan kimia perairan maupun ketersediaan pakan akan menyebabkan pola sebaran dari populasi kerang kepah cenderung seragam. Penyebaran yang mengelompok besar kemungkinan disebabkan karena adanya perbedaan faktor lingkungan yang mendukung kehidupan organisme bivalvia sehingga membatasi spesies tertentu untuk menyebar secara seragam atau acak di semua tingkatan pengambilan contoh (Rizal et al., 2013).

Faktor fisika dan kimia yang hampir merata pada suatu habitat serta tersedianya makanan bagi hewan yang hidup di dalamnya sangat menentukan hewan tersebut hidup berkelompok, acak, maupun normal (Suin, 2002). Faktor luar yang mempengaruhi kelimpahan dan distribusi suatu biota adalah perubahan lingkungan akibat aktivitas manusia dalam memanfaatkan lingkungan, misalnya penanaman rumput laut, pengerukkan pantai, penimbunan pantai dan pemanfaatan kayu dari hutan bakau (Malau, 2002). Pola penyebaran seragam diduga karena terdapat kemiripan parameter lingkungan diantaranya $\mathrm{pH}$ air, $\mathrm{pH}$ substrat dan tipe substrat. Sedangkan untuk organisme dengan pola penyebaran secara acak di duga karena faktor lingkungan yang seragam seperti nilai pH air (Dayanti et al., 2016).

\subsection{Distribusi Frekuensi Ukuran P.erosa}

Hasil pengukuran terhadap panjang cangkang kerang kepah ( $P$. erosa) dapat dilihat pada Gambar 3. Dari hasil pengukuran individu di laboratorium, ukuran kerang kepah $P$. erosa yang paling banyak ditemukan yaitu kerang yang berukuran 3,52 - 3,91 (kelas 6) sebanyak 40 individu dan yang paling sedikit ditemukan yaitu kerang berukuran 1,52 - 1,91 (kelas 1) sebanyak 1 individu. Spesies yang sama pada lokasi yang berbeda akan memiliki pertumbuhan yang berbeda karena adanya perbedaan faktor yang mempengaruhi pertumbuhan tersebut (Nurdin et al., 2006). Kerang kepah di perairan muara Sungai Tiram 
ini menunjukkan ukuran yang berbeda-beda. Keberadaan kerang kepah di perairan ini yang menunjukkan ukuran yang berbeda-beda juga dipengaruhi oleh aktivitas penangkapan keran yang dilakukan oleh masyarakat sekitar. Masyarakat sekitar muara Sungai Tiram menangkap kerang kepah tanpa memperhatikan kelangsungan dan siklus hidup kerang kepah tersebut.

Menurut Dody (2010) perbandingan laju pertumbuhan dengan ukuran cangkang yang berbeda menunjukkan kecepatan pertumbuhan tiap individu tidak sama. Hal ini disebabkan oleh kemampuan dalam memanfaatkan energi serta meminimalisir pengaruh faktor fisiologis dan faktor-faktor lainnya. Hal ini sejalan dengan pernyataan Sakila et al. (2018) bahwa perbedaan frekuensi tersebut disebabkan oleh kondisi lingkungan yang kurang optimum, keturunan, jenis kelamin, umur, prasit, makanan, suhu, dan kualitas air. Hal ini sejalan dengan pernyataan Suryanti et al. (2010) bahwa energi dan stok nutrisi yang didapatkan bivalva dari makanannya yang selanjutnya dialokasikan pertama untuk metabolisme, kedua untuk reproduksi, dan terakhir untuk pertumbuhan.
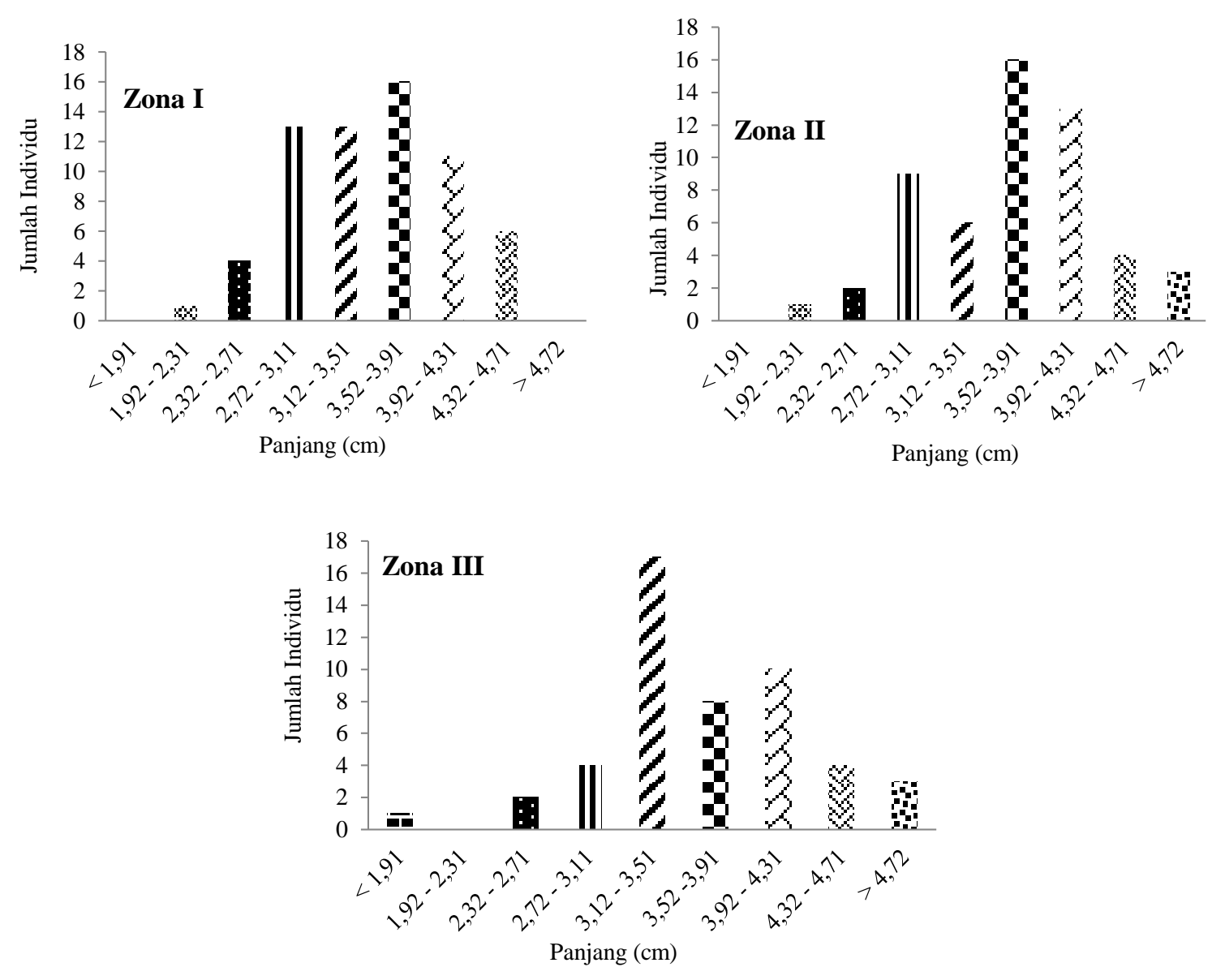

Gambar 3. Distribusi Frekuensi Ukuran P. erosa pada masing-masing Zona Pengamatan di kawasan mangrove muara Sungai Tiram

\section{Kesimpulan dan Saran}

Berdasarkan hasil penelitian dapat disimpulkan bahwa karakterisik habitat kerang kepah (P. erosa) yang diukur memiliki nilai rata-rata suhu $30^{\circ} \mathrm{C}$, salinitas $6 \mathrm{ppt}$, $\mathrm{pH}$, kandungan bahan organik total sedimen berkisar antara 2,48-2,98\%, dan bahan padatan tersuspensi memiliki nilai berkisar anta 10-20 mg/L yang cukup baik untuk pertumbuhan kerang kepah. Kelimpahan kerang kepah di kawasan mangrove muara Sungai Tiram ini tergolong rendah dan tidak ada perbedaan kelimpahan kerang kepah pada masing-masing zona pengamatan. Pola distribusi kerang kepah antar zona pengamatan lebih bersifat merata yang 
didominasi oleh ukuran 3,52-3,91 $\mathrm{cm}$ dan paling sedikit berukuran $<1,91 \mathrm{~cm}$.

Pada penelitian selanjutnya, disarankan untuk meneliti mengenai parameter habitat yang lain seperti fraksi sedimen pada habitat kerang kepah ( $P$. erosa). Diharapkan untuk masyarakat sekitar kawasan mangrove muara Sungai Tiram dan pemerintah setempat untuk tetap menjaga kawasan mangrove muara Sungai Tiram agar organisme dan juga mangrove yang hidup di kawasan tersebut tetap terjaga

\section{Daftar Pustaka}

Akbar J., Bahtiar, E. Ishak. (2014). Studi Morfometrik Kerang Kalandue (Polymesoda erosa) di Hutan Mangrove Teluk Kendari. Jurnal Mina Laut Indonesia, 4(1):1-14.

Alfiansyah, A. (2014). Struktur Komunitas Bivalvia pada Kawasan Ekosistem Lamun di Perairan Teluk Dalam. Universitas Maritim Raja Ali Haji. Tanjung Pinang.

Amin, R. (2009). Sebaran Densitas Kerang Kepah (Polymesoda erosa) di Perairan Pemangkat Kebupaten Sambas Kalimantan Barat. Tesis. Fakultas Perikanan dan Ilmu Kelautan. Universitas Diponegoro. Semarang.

Brower, J., Z. Jerrold, C. Von Ende. (1990). Field and Laboratory Methods for General Zoology. Third edition. United States of America: W.M.C Brown Publisher. America.

Dahuri, R. (2004). Pengelolaan Sumber Daya Wilayah Pesisir dan Lautan Secara Terpadu. Penerbit Pradnya Paramita. Jakarta.

Dayanti, F., Bahtiar, dan E. Ishak. (2016). Kepadatan dan Distribusi Kerang Bulu (Anadara antiquata L, 1758) di perairan Wangi-wangi Selatan Desa Numana Kabupaten Wakatobi. Jurnal Manajemen Sumber Daya Perairan, 2(2):113-122.

Dody, S. (2010). Morfometrik dan Pertumbuhan Kerang Tapes (Tapes literatus) di Pulau Fair, Maluku Tenggara. Prosiding Seminar Riptek Kelautan Nasional, Ancol Timur. Jakarta.

Dwiono, S.A.P. (2003). Pengenalan Kerang Mangrove Geloina erosa dan Geloina expansa. Balitbang Sumberdaya Laut, Pusat Penelitian Oseanografi-LIPI. Jakarta. Oceana, 2:31-38.

Effendi, H. (2003). Telaah Kualitas Air Bagi Pengelolaan Sumberdaya Lingkungan.

Habonaran, J., S. Nasution, Thamrin. (2015). Diversity of Macrozoobenthos in Kuala Indragiri Coastal Water Riau Province. Jurnal Online Mahasiswa Fakultas Perikanan dan Ilmu Kelautan Universitas Riau, 2(2):1-11.

Hamidah, A. (2000). Keragaman dan Kelimpahan Moluska di Bagian Utara Danau Kerinci Jambi. Tesis. Institut Pertanian Bogor. Bogor.

Jewlaika, L., Mubarak, M., dan Nurrachmi, I. (2014). Studi padatan tersuspensi di perairan Pulau Topang Kabupaten Kepulauan Meranti Provinsi Riau. Jurnal Perikanan dan Kelautan, 19(1): 53-66.

Junaidi, E.E, .P. Sagala, dan Joko. (2010). Kelimpahan Populasi dan Pola Distribusi Remis (Corbicula sp.) di Sungai Borang Kabupaten Banyuasin. Jurnal Penelitian Sains, 13(3):50-54.

Kelana P. P., I. Setyobudiandi, M. Krisanti, 2015. Kondisi Habitat Polymesoda erosa pada Kawasan Ekosistem Mangrove Cagar Alam Leuweung Sancang. Jurnal Akuatik, VI (1):107117.

Malau, R.D.Y. (2002). Studi Hubungan Kualitas Habitat terhadap Pola Distribusi Kerang Kerek Gafrarium spp. pada Ekosistem Padang Lamun Gugus Pulau Pari. Kepulauan Seribu. Tesis. FPIK. IPB.

Marwanto, M.R., M.S. Answari, S. Rifanjani. (2018). Pengaruh Tekstur, Kandungan Air dan Salinitas Tanah terhadap Kelimpahan Kerang Kepah (Polymesoda erosa) di Hutan Mangrove Desa Sungai Bakau Kecil Kabupaten Mempawah. Jurnal Hutan Lestari, 6(1):208-215.

Melinda, M., P.S. Sari, dan D. Rosalina. (2015). Kebiasaan Makan Kerang Kepah (Polymesoda erosa) di Kawasan Mangrove Pantai Pasir Padi. Oseatek, 9 (1):35-44.

Nontji, A. (2007). Laut Nusantara. Edisi Revisi Cetakan Kelima. Djambatan. Jakarta. 
Nugroho, F., V. Amrifo dan R. Taibin. (2009). Buku Ajar Statistika Dasar (Edisi Revisi). Pusaka Riau. Pekanbaru.

Nurdin, J., N. Marusin, Izmiarti, A. Asmara, R. Deswandi, J. Marzuki. (2006). Kepadatan Populasi dan Pertumbuhan Kerang Darah Anadara antiquata L. (bivalvia: Arcidae) di Teluk Sungai Pisang, Kota Padang, Sumatera Barat. Makara Sains. 10 (2):96-101.

Pemuji, A.M., R. Muskananfola, dan C. Ain. (2015). Pengaruh Sedimentasi terhadap Kelimpahan Makrozoobenthos di Muara Sungai Betah Walang Kabupaten Demak. Jurnal Saintek Perikanan, 10(2):129-135.

Radojevic, M. and V.N, Bashkin. (1999). Practical Environment Analysis. Royal Society of Chemistry.

Rizal., Emiyarti, dan Abdullah. (2013). Pola Distribusi dan Kepadatan Kijing Taiwan (Anadonta woodiana) di Sungai Aworeka Kabupaten Konawe. Jurnal Mina Laut Indonesia, 2 (6): 142-153.

Sakila, N., D.A. Ramadhani dan A. Suryati. (2018). Pertumbuhan dan Struktur Umur Kerang Kepah (Meretrix meretrix) di Kampung Nipah Desa Sei Nagalawan Kecamatan Perbaungan Kabupaten Serdang Bedagai. Journal of Marine and Aquatic Science, 4(2):316323.

SNI. (2004). Air dan Air Limbah - Bagian 3 : Cara Uji Padatan Tersuspensi Total (Total Suspended Solid, TSS) Secara Gravimetri.

Snedecor, G.W. dan Cochran, W.G. (1980). Statistical Methods. Seventh Edition. Ames. Iowa State University Press.
Solihudin, M. E. Sari, dan G. Kusumah. (2011). Prediksi Laju Sedimentasi di Perairan Pemangkat Sambas Kalimantan Barat Menggunakan Metode Permodelan. Jakarta. Buletin Geologi Tata Lingkungan, 21(3):117126.

Suin, N.M. (2002). Pengukuran Faktor Lingkungan Biotic. Jurusan biologi FIMIPA. Universitas Andalas. Padang.

Suryanti, A., I. Widowati dan Suriharyono. (2010). Tingkat Kematangan Gonad Betina Kerang Totok (Polymesoda erosa) dari Segara Anakan Cilacap. Prosiding Seminar Nasional Universitas Jenderal Soedirman: 119125.

Suryanto dan Utojo. (2002). Pertumbuhan Tiram pada Penyebaran yang Berbedabeda. Jurnal Penelitian Budidaya Pantai.

Susanti., N.E. Fajri., R.M. Putra. (2013). Community of Bivalves in Mangrove Area Mesjid Lama Village, Talawi Subdistrict Batubara Regency, Sumatera Utara Province. Jurnal Online Mahasiswa Fakultas Perikanan dan Ilmu Kelautan Universitas Riau, 1(1):116.

Widigdo, B. (2000). Diperlukan Pembukuan Kriteria Eko-Biologis untuk Menentukan Potensi Alami Kawasan Pesisir untuk Budidaya Udang. Prosiding Pelatihan untuk Pelatih Pengelolaan Wilayah Pesisir Terpadu. PKSPL. IPB. Bogor. 